\title{
Chaparral shrub recovery after fuel reduction: a comparison of prescribed fire and mastication techniques
}

\author{
Jennifer B. Potts $\cdot$ Eva Marino $\cdot$ Scott L. Stephens
}

Received: 1 August 2009/Accepted: 7 March 2010/Published online: 23 March 2010

(C) The Author(s) 2010. This article is published with open access at Springerlink.com

\begin{abstract}
Fuel management techniques are commonly used in shrublands to reduce wildfire risk. However, more information about the ecological effects of these treatments is needed by managers and ecologists. In an effort to address this need, we performed a replicated (4 replicates per treatment) 48-ha experiment in northern California chaparral dominated by Adenostoma fasciculatum to determine the effects of two fuel reduction types (prescribed fire and mastication) and three different seasons of treatment (fall, winter, and spring) on shrub cover, height, and seedling density. Exclosures $\left(2.5 \mathrm{~m}^{2}\right.$ each) were also used to assess herbivory effects. By the third posttreatment year, prescribed fire treatments had higher shrub cover $(71 \pm 2 \%)$ than mastication $(43 \pm 4 \%)$. There was no treatment effect on shrub height, species richness, or composition. Seedling density was initially higher in prescribed fire treatments $(31 \pm 4$ seedlings $\left.\mathrm{m}^{-2}\right)$ than mastication $\left(3 \pm 0\right.$ seedlings $\left.\mathrm{m}^{-2}\right)$; however, prescribed fire treatments experienced
\end{abstract}

J. B. Potts · E. Marino - S. L. Stephens $(\bowtie)$

Division of Ecosystem Science, Department of Environmental Science, Policy and Management, University of California, 137 Mulford Hall, Berkeley, CA 94720-3114, USA

e-mail: sstephens@berkeley.edu

E. Marino

Laboratorio de Incendios Forestales, Centro de Investigación Forestal, Instituto Nacional de Investigación y Tecnología Agraria y Alimentaria, Ctra. La Coruña km 7.5, 28040 Madrid, Spain substantial mortality, especially spring burning, resulting in lower densities 3 years after treatments $\left(18 \pm 0\right.$ seedlings $\mathrm{m}^{-2}$ after fall and winter fire compared to $2 \pm 0$ seedlings $\mathrm{m}^{-2}$ after spring fire). A. fasciculatum remained the dominant shrub species after the treatments, and Ceanothus cuneatus recruitment was higher in fall burning. Deer herbivory only affected shrub height, especially in masticated units, resulting in heights of $55 \pm 2 \mathrm{~cm}$ in unexclosed areas compared to $66 \pm 4 \mathrm{~cm}$ inside exclosures by the third post-treatment year. Overall, our findings suggest that fuel treatments play an important role in shrubland community dynamics, at least in the short-term, with implications for re-treatment frequency, community structure, and wildlife habitat.

Keywords Prescribed burning - Mastication · Resprouting · Fire hazard · Herbivory · Chamise $\cdot$ Adenostoma fasciculatum .

Ceanothus cuneatus

\section{Introduction}

Fuels reduction treatments have become a common practice for reducing the negative impacts of wildfire to human communities (Gill and Stephens 2009; Stephens et al. 2009), but unfortunately, managers are lacking specific details regarding trade-offs and 
effects of differing treatment types and seasons in shrub-dominated ecosystems. To address existing knowledge gaps, we examined shrub community response to five of the most commonly practiced fuel reduction treatments in shrublands ecosystems. We focus our analysis on sprouting shrub species due to their unique life history strategies (Bond and van Wilgen 1996) and overwhelming influence on the broader chaparral plant community. Fuel reduction, by its inherent nature of being a disturbance, will affect each plant species differently depending upon the species' ability to survive and regenerate.

Shrubland plant species can be grouped into three categories, or functional groups, depending upon their post-disturbance regeneration response: obligate seeders, obligate sprouters, and facultative seeders (Keeley 1991; Wells 1969). The first functional group, obligate seeders, primarily reproduce from a long-lived firestimulated soil-stored (e.g., Ceanothus cuneatus, Arctostaphylos manzanita) or canopy-stored (e.g. Banksia) seed banks and lack any sprouting ability. Due to their dependency on fire-related seed germination cues, very few obligate seeder seedlings are expected to emerge after mechanical treatments. In contrast, obligate sprouting species (the second functional group) regenerate primarily by sprouting vigorously from adventitious buds (e.g., Arctostaphylos glandulosa, Quercus berberidifolia). These species are expected to regenerate well after both fire and mastication treatments, but fewer resprouting species may sprout following high intensity fires, since high levels of soil heating may damage meristematic tissues. Obligate sprouters can also reproduce from seed, but most species only produce a few seeds that are intolerant of heat exposure (e.g., Quercus spp.), and only a small number of species (e.g., A. glandulosa) produce seeds that require fire cues, such as smoke, heat, and charate to stimulate germination (Keeley 1987, 1991). The third functional group, facultative seeders, reproduces both sexually by seed and vegetatively by sprouting (e.g., Adenostoma fasciculatum, chamise). The seed bank of facultative seeders is often polymorphic, containing both fire-stimulated and firesensitive seeds to ensure germination after and between fire events (Keeley 1991; Zammit and Zedler 1988), therefore, we expect this group to have a strong recovery after disturbance.

Seasonal timing of fuel treatments is an important management consideration due to its influence on the reproductive success of each functional group. For example, vegetative tissues vary in their sensitivity and regeneration ability in different seasons. In a wet season fire, low fire intensities may fail to release seed dormancy for many obligate seeders, but vegetative growth from resprouters may be more prolific since less bud tissue is damaged. Conversely, burning during active growth can increase mortality due to increased tissue sensitivity (Florence and Florence 1988). Seasonal timing is also an important determinant of seed survival. Many soft-coated seeds (facultative seeders, obligate sprouters) absorb water after rainfall and become more vulnerable to heat (LeFer and Parker 2005). Warmer, drier season prescribed fires, in contrast, may produce high enough temperatures to crack the hard seed coats of most obligate seeders, but these high fire intensities may also cause greater mortality for sprouting shrub species and heat sensitive seeds. The season of treatment will also strongly affect germinant survival. A seed that breaks dormancy after a fall treatment will have several months to establish a root system before the summer drought, whereas a spring germinant may not have adequate time to develop roots, and is more susceptible to drought-related mortality (Florence and Florence 1988). Prescribed fires and mastication can also influence non-native plant establishment and the associated resource competition (Potts and Stephens 2009).

Shrub growth patterns can be altered due to different physiological activity during the burn time (Drewa et al. 2002; Radosevich and Conard 1980; Bond and van Wilgen 1996). Lower resprouting shrub cover after spring treatments would be expected because carbohydrate and water reserves have already been partially expended. Fire treatments not only affect aboveground vegetation but also can change soil properties. When organic matter is consumed by fire, plant nutrients are released and become highly available for plant growth (DeBano et al. 1979). Soil heating by fire can also change water repellency (DeBano 2000) and therefore, prescribed burning may have a different impact on seedling recruitment. Community composition after fuel treatments may affect future fire potential. Adenostoma is considered more flammable than Ceanothus (Biswell 1974). A shift in community composition that favors Adenostoma may ultimately create a higher risk fire environment. 
Herbivores can have a strong selective pressure on species composition and abundance in shrublands (Manier and Hobbs 2007), particularly after disturbance when regenerating plants are easily accessible and provide high levels of nutrition. Obligate seeder species that depend exclusively on their seed bank for regeneration are particularly vulnerable to seed predators, while obligate sprouting species can be heavily influenced by vegetative browsers (O'Neil and Parker 2005).

Due to the abundance of large herbivores in our research vicinity, including black-tailed deer (Odocoileus hemionus), rabbits (Lepus californicus and Sylvilagus), and rodents (Dipodomys agilis, Peromyscus spp., Neotoma spp.), there is the potential for a pronounced herbivore impact on the regenerating plant community. Herbivores may have different effects on plant recovery in each fuel treatment, since the type and season of treatment can result in a unique interaction between plant phenology and browsing intensity. For example, spring treatments would top-kill many sprouting species at the time of low carbohydrate and water reserves, leaving the plant with few resources to regenerate in the coincident period of heaviest browsing intensity (Moreno and Oechel 1991).

Herbivore preferences for particular plant species may also influence the character of the recovering shrub community. Mills (1986) found that mammalian herbivores significantly decreased the abundance and survivorship of Ceanothus seedlings after fire. In their 3-year study, herbivore selectivity for Ceanothus increased over time and gave Adenostoma a competitive advantage. Adenostoma, however, may also succumb to deer browsing with sharply reduced resprouting vigor (Davis 1967).

Although many important studies have examined plant recovery after fire, a majority of research lacks treatment replication (Beyers and Wakeman 2000; Dunne et al. 1991), management appropriate spatial scales (Moreno and Oechel 1991; Tyler 1995), or field settings (Keeley 1987; LeFer and Parker 2005). Many of the field studies have been performed opportunistically after wildfires rather than replicated prescribed fires (Moreno and Oechel 1991; Tyler 1995; Zammit and Zedler 1988). Furthermore, mastication studies are rare in the peer-reviewed literature, and comparative, replicated studies of prescribed fire and mastication have rarely been conducted in the chaparral ecosystem.
The goal of our study is to examine the ecological responses of the most common fuel treatments in chaparral including (a) fall prescribed fire, (b) winter prescribed fire, (c) spring prescribed fire, (d) fall mastication (slashing), and (e) spring mastication. In our research, we address three questions: (1) Does fuel treatment type and/or season affect sprouting shrub cover, (2) Does fuel treatment type and/or season affect shrub seedling survival, and (3) Does herbivory affect sprouting and seeding species recovery after treatments. Information from this study should be useful to managers and ecologists interested in shrubland ecosystems in Mediterranean climates.

\section{Methods}

Study site

We conducted our study in northern California's Coast Range chaparral, approximately $50 \mathrm{~km}$ inland from the Pacific Ocean and $175 \mathrm{~km}$ north of San Francisco, CA $\left(39^{\circ} \mathrm{N}, 123^{\circ} \mathrm{W}\right)$. Study sites are representative of Californian Adenostoma fasciculatum (chamise) chaparral, with chamise being the dominant species ( $>65 \%$ of the overstory cover), and Ceanothus cuneatus (buckbrush) and Arctostaphylos (manzanita) species occupying more minor overstory components. Pre-treatment vegetation averaged 1$2 \mathrm{~m}$ in height and nearly $100 \%$ shrub cover. Nearby vegetation types include mixed oak woodland on mesic, north-facing slopes and knobcone pine (Pinus attenuata) stands on ridge tops and east-facing slopes. Chamise-dominated chaparral occupies large areas in the northern coastal ranges of California.

The research area experiences a typical Mediterranean climate with hot, dry summers and cool, wet winters. Maximum mean temperatures vary widely throughout the year, averaging $34^{\circ} \mathrm{C}$ in summer and $7^{\circ} \mathrm{C}$ in winter. The 30 -year rainfall average is $100 \mathrm{~cm}$, with nearly all precipitation occurring between October and May. Annual rainfall during our 2001-2005 study averaged $99.0 \mathrm{~cm}$ and ranged from 90.7 to $124.5 \mathrm{~cm}$. Treatment areas are located $700-1,000 \mathrm{~m}$ above sea level on south and west aspects with slopes of $25-55 \%$. Soils are derived from weathered sandstone and shale and are classified as shallow, rocky, and moderately acidic. Fire-return intervals for these ecosystems before fire suppression 
were approximately 30-70 years (Stephens et al. 2007). Fire and other major disturbances were absent from the study area for at least 40 years prior to treatment.

\section{Experimental design}

Each of the five fuel reduction treatments was replicated four times; in addition, four control plots were also installed in the study area (total of 24 experimental units). Each experimental unit was approximately 2 ha, and units were distributed across a $<2 \mathrm{~km}$ distance. Treatment type (prescribed fire or mastication) and season (fall/winter/spring) were randomly assigned to the experimental units, although mastication was restricted to sites with slightly more gradual slopes due to limited equipment maneuverability in steep terrain. Treatment seasons were defined as: Fall (3-20 November), Winter (8-18 January), and Spring (31 March-3 April for prescribed fire, and 23 April-2 June for spring mastication). Spring mastication treatments were conducted slightly later than spring fire treatments because roads were not dry enough for the masticator to access. We did not expect this discrepancy in spring treatment timing to significantly affect our findings, since previous analysis showed that treatment type (prescribed fire or mastication) overshadowed the effect of treatment season (Potts and Stephens 2009).

We performed fuel reduction treatments between 2001 and 2003 at the University of California Hopland Research and Extension Center and adjacent US Bureau of Land Management South Cow Mountain Recreation Area. Our initial goal was to complete all four replicates of each treatment within the same year, but unfavorable weather conditions and equipment availability forced us to split replicates over 2 years.

Prescribed fires were ignited with driptorches to produce upslope headfires (Stephens et al. 2008). Mastication was performed by a track bulldozer with a front mounted rotating toothed drum which shredded aboveground biomass into a patchy layer $(<5 \mathrm{~cm}$ deep) of woody debris that remained on the soil surface. Particle size ranged from 10 to $40 \mathrm{~cm}$ in length by $5-10 \mathrm{~cm}$ in width. Sub-surface soil and root systems were not disturbed by the masticator. Treatment heterogeneity was minimal in mastication treatments, since the equipment operator performed systematic passes through the vegetation. Vegetation mortality was $90-100 \%$ in both fire and mastication treatments. We did not implement a winter mastication treatment due to unpredictable road access and potential soil damage caused by the heavy machinery in wet conditions.

\section{Monitoring}

We installed 15 permanent line transects in each experimental unit prior to fire or mastication to measure shrub cover using the line intercept method. Transects were $15 \mathrm{~m}$ in length and randomly placed throughout the experimental unit; cover was measured by placing a tape along the transect and continuously recording cover by species or bare ground. Shrub height $(\mathrm{cm})$ was measured at $5 \mathrm{~m}$ intervals along each line transect. Data from the 15 line transects were pooled to represent the experimental unit. At the endpoints of 10 randomly selected transects, we established permanent $2.5 \mathrm{~m}^{2}$ vegetation sampling quadrats to determine seedling abundance and composition. As with the transect data, we pooled seedling data from the 10 quadrats to represent the experimental unit. We monitored shrub and seedling data prior to treatment and again during the second and third summers after treatment. Control plots (4 replicates) were monitored before treatments were installed to determine a baseline range of variability among treatment units. A subset of control plots was monitored each year and showed no significant change in height, cover, or composition. This finding is similar in other studies that also show very little change in mature chaparral stands over the study period in terms of cover and height (Hanes 1971).

Immediately after the fuel treatment, we randomly selected five of the 10 seedling quadrats for herbivore exclosures. We constructed exclosures around these quadrats, including a $20 \mathrm{~cm}$ buffer zone, for a total exclosed area of $12.5 \mathrm{~m}^{2}$ for each experimental unit. Exclosures were built with $1.5 \mathrm{~m}$ tall wire mesh that was composed of $1.27 \mathrm{~cm}$ squares. We supported the mesh with metal t-posts that were driven into the soil. We did not add roof coverings because we did not expect herbivores to climb or jump over the mesh sides, and we wanted to minimize shading, moisture accumulation and other indirect exclosure effects. Exclosures were initially designed to eliminate deer, rabbit, and rodent browsing, but erosion created gaps 
beneath the wire mesh that were large enough for small animal entry. Although we believe that the exclosures deterred most small mammals, we can only be confident that the exclosure completely excluded black-tailed deer.

\section{Statistical analysis}

One-way analysis of variance (ANOVA) was used to check for differences between control and manipulated plots before treatments $(n=4)$. Factorial ANOVA was used to assess treatment type and herbivory effect on shrub height, cover, and seedling abundance after treatments. In these ANOVA tests, the treatment factor had five levels, one for each treatment type (FF = fire fall, $\mathrm{FS}=$ fire spring, $\mathrm{FW}=$ fire winter, $\mathrm{MF}=$ mastication fall, $\mathrm{MS}=$ mastication spring); and the exclosure factor had two levels (exclosed and unexclosed). This factorial ANOVA has the advantage to be able to identify potential statistical interactions between factors affecting shrub response. Species richness and composition were only assessed in the unexclosed areas because exclosure size was not large enough to address species diversity. We also performed repeated measures ANOVA to address treatment effect (between groups factor) on shrub cover over time (within subject factor) in the unexclosed areas. We present data from the second and third posttreatment years, and exclude data from the first posttreatment year because spring treatments did not have time to produce new growth before the summer monitoring period. We applied power, logarithm, and angular (arcsine square root) transformations to the seedling data to meet ANOVA assumptions. We used a non-parametric test (Kruskal-Wallis) when data transformation was not sufficient to meet ANOVA assumptions. Tukey HSD tests were performed to identify differences between treatment types when ANOVA results demonstrated significant effects $(P<0.05)$. Statistical analyses were done with the $\mathrm{R}$ statistical software package (http://www.r-project.org/).

\section{Results}

Shrub cover and height

Control plots had no significant differences in shrub cover $\quad\left(F_{5,18}=1.55, \quad P=0.224\right) \quad$ or height
$\left(F_{5,18}=0.39, P=0.846\right)$ compared to experimental plots before treatments were applied. Exclosed areas only had significantly taller shrubs than unexclosed areas on the third post-treatment year $\left(F_{1,30}=1.16\right.$, $P=0.290$ for the second year and $F_{1,30}=5.27$, $P=0.028$ for the third year; Fig. 1). Treatment type had no significant effect on shrub height $\left(F_{4,30}=1.99\right.$, $P=0.122$ and $F_{4,30}=1.45, P=0.242$ for the second and third year, respectively), and no interaction between factors was observed. In general, fire treatments tended to have taller shrubs than mastication treatments outside the exclosures in the third year.

Regarding shrub cover, there was no significant difference between exclosed and unexclosed areas for both post-treatment years $\left(F_{1,30}=0.28, P=0.601\right.$ for the second year and $F_{1,30}=0.82, P=0.371$ for the third year). However, shrub cover was significantly different by treatment type, with $P<0.0001$ in both years $\left(F_{4,30}=9.90\right.$ for the second year and $F_{4,30}=11.64$ for the third year), and no significant interaction between treatment type and exclosure. Therefore, to better address cover differences between treatments, we decided to exclude data from the exclosures in the following analyses.

Repeated measures ANOVA in the unexclosed areas confirmed a highly significant effect of treatment type on shrub cover $\left(F_{4,45}=29.76, P<0.0001\right.$; Fig. 2). In general, fire treatments had higher cover

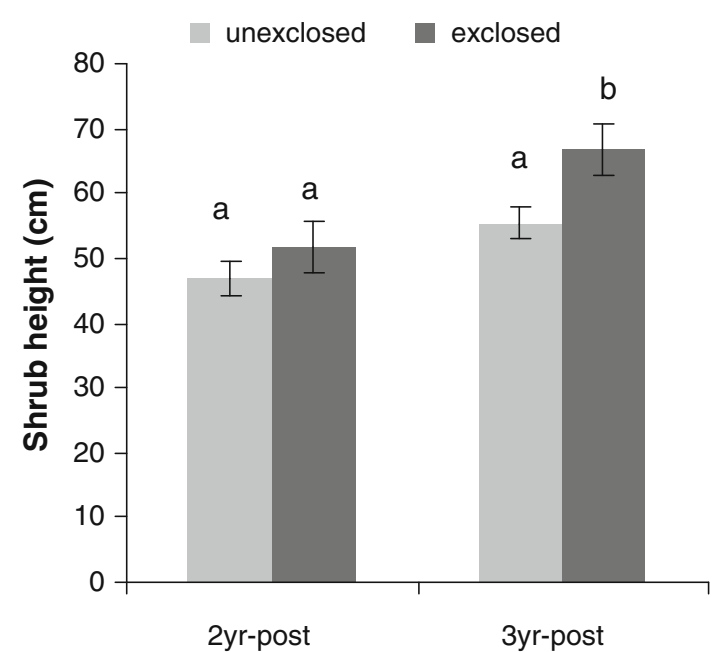

Fig. 1 Average shrub height $( \pm 1 \mathrm{SE})$ for exclosed and unexclosed areas and post-treatment year (second year posttreatment and third year post-treatment). Different letters depict significant differences in height between treatments within each year for a significance level $\alpha=0.05$ 


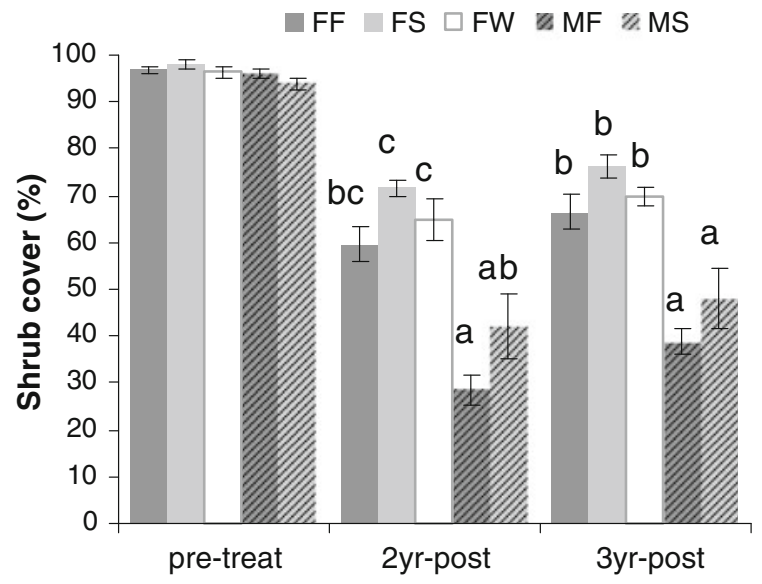

Fig. 2 Average shrub cover $( \pm 1 \mathrm{SE})$ for each treatment $(F F$ fire fall, $F S$ fire spring, $F W$ fire winter, $M F$ mastication fall, $M S$ mastication spring) and monitoring time (pre-treatment, second year post-treatment and third year post-treatment). Different letters depict significant differences in cover between treatments within each year for a significance level $\alpha=0.05$

values than mastication treatments, except for the second year where mechanical spring and fall fire were not significantly different from each other. Prescribed fire plots had a shrub cover ranging from 59 to $72 \%$ by the second year and $67-76 \%$ by the third year, compared to mastication plot cover of $29-42 \%$ and $39-48 \%$, in the second and third years, respectively. Treatment season did not affect shrub recovery.

The change in shrub cover over time (within subject factor) was highly significant $\left(F_{2,45}=244.98\right.$, $P<0.0001)$. Shrub cover reduction for both prescribed fire and mastication was significant, with cover values remaining significantly lower than pre-treatment values 3 years after treatments were applied. However, cover increase between the second and the third year was not significant within any treatment type, although MF tended to have a slightly higher recovery rate (Tukey HSD, $P=0.064$ ).

Species richness and composition

Species composition and richness were assessed outside exclosures. Prior to treatments, we found 14 shrub species along the cover transects, with an average of $6 \pm 1$ species per experimental unit. Adenostoma fasciculatum was the overwhelmingly dominant species (76\% average cover; Table 1), followed by Ceanothus cuneatus (11\%), Arctostaphylos species (6\%), Heteromeles arbutifolia (1\%), and Quercus species $(<1 \%)$. After treatments, we identified 16 shrub species along the cover transects. Species richness did not differ between treatments $\left(F_{4,15}=1.52, P=0.247\right.$ for the second year and Kruskal-Wallis $\chi^{2}=8.03, P=0.090$, for the third year) with an average of $4 \pm 1$ species in the second year and $5 \pm 1$ species in the third year. Adenostoma was the primary species 3 years after treatments, with similar relative cover between treatments $\left(F_{4,15}=0.45, P=0.774\right)$ ranging from 91 to $95 \%$, but different total cover between treatments $\left(F_{4,15}=17.86, P<0.0001\right)$, with fire treatments showing significant higher values of this species compared to mastication. The remaining 15 species occupied $<1 \%$ cover each by the third post-treatment year. Ceanothus cuneatus averaged only $0.9 \%$ total cover and up to $2 \%$ relative cover after 3 years and never exceeded $2.5 \%$ total cover or $6.5 \%$ relative cover in any experimental unit. The fall fire treatment had significantly higher Ceanothus cuneatus total and relative cover compared to the spring and winter fire

Table 1 Average \pm SE shrub cover $(\%)$ by species for each treatment type (fire fall, fire spring, fire winter, mastication fall, and mastication spring) before (pre-treatment) and 3 years after treatments ( 3 yr-post) in northern California chaparral

\begin{tabular}{|c|c|c|c|c|c|c|}
\hline \multirow[t]{2}{*}{ Species } & \multirow[t]{2}{*}{ Year } & \multicolumn{3}{|l|}{ Fire } & \multicolumn{2}{|l|}{ Mastication } \\
\hline & & Fall & Spring & Winter & Fall & Spring \\
\hline \multirow[t]{2}{*}{ Adenostoma fasciculatum } & Pre-treatment & $75.1 \pm 4.5$ & $78.1 \pm 3.3$ & $75.1 \pm 6.3$ & $80.7 \pm 2.0$ & $73.9 \pm 4.4$ \\
\hline & 3 yr-post & $63.3 \pm 4.0$ & $72.0 \pm 1.3$ & $65.0 \pm 2.3$ & $36.5 \pm 3.3$ & $43.3 \pm 5.6$ \\
\hline \multirow[t]{2}{*}{ Ceanothus cuneatus } & Pre-treatment & $16.2 \pm 2.8$ & $15.5 \pm 3.5$ & $8.4 \pm 4.5$ & $9.0 \pm 2.3$ & $9.9 \pm 3.8$ \\
\hline & 3 yr-post & $0.9 \pm 0.3$ & $0.0 \pm 0.0$ & $0.0 \pm 0.0$ & $0.4 \pm 0.2$ & $0.5 \pm 0.2$ \\
\hline \multirow[t]{2}{*}{ Other shrub spp. } & Pre-treatment & $5.6 \pm 2.3$ & $4.4 \pm 2.9$ & $12.8 \pm 4.5$ & $6.6 \pm 2.0$ & $10.1 \pm 1.5$ \\
\hline & 3 yr-post & $3.1 \pm 1.5$ & $4.3 \pm 2.3$ & $5.0 \pm 1.1$ & $1.7 \pm 0.9$ & $3.8 \pm 1.5$ \\
\hline
\end{tabular}


treatments by the third post-treatment year $\left(F_{4,15}=8.25, \quad P<0.001\right.$ in total cover and $F_{4,15}=8.96, P<0.001$ in relative cover).

\section{Seedling establishment}

Total shrub seedling density was significantly different between treatments in both the second and third post-treatment years $\left(F_{4,30}=29.28, P<0.0001\right.$ for the second year and $F_{4,30}=26.15, P<0.0001$ for the third year), but did not differ between exclosed and unexclosed areas $\left(F_{1,30}=0.03, P=0.862\right.$ for the second year, and $F_{1,30}=0.58, P=0.449$, for the third year). In the second post-treatment year, all fire treatments had considerably higher seedling densities than the mastication treatments, with an average of $31 \pm 4$ seedlings $\mathrm{m}^{-2}$ (mean \pm standard error) in the fire treatments compared to $3 \pm 0$ seedlings $\mathrm{m}^{-2}$ in the masticated areas. By the third post-treatment year, the spring fire treatment had experienced disproportionately higher mortality and exhibited seedling densities that were much more similar to the mastication treatments than to the other fire treatments. At the end of the third post-treatment year, the fall and winter prescribed fire treatments had significantly higher seedling densities, with $19 \pm 3$ and $18 \pm 4$ seedlings $\mathrm{m}^{-2}$, respectively, compared to $3 \pm 1$ seedlings $\mathrm{m}^{-2}$ in the spring fire treatment and $2 \pm 0$ seedlings $\mathrm{m}^{-2}$ in the masticated areas.

Adenostoma was the most common shrub seedling in all experimental units (Fig. 3). Adenostoma seedling density significantly differed between treatments in both post-treatment years $\left(F_{4,15}=9.16, P<0.001\right.$ for the second year and $F_{4,15}=15.10, P<0.0001$ for the third year). In the second post-treatment year, Adenostoma seedling density was considerably higher in the fire treatments than in mastication treatments, although average seedling density for the spring burn units was largely boosted by a single treatment replicate with high seedling numbers. By the third posttreatment year, high seedling mortality in spring burn units reduced Adenostoma seedlings to similar densities as in mastication treatments. Fall and winter fire treatments still had higher Adenostoma seedling abundance compared to the other treatments.

Ceanothus cuneatus was the second most abundant plant species in the post-treatment units. This species also showed significantly different seedling densities between treatments in both the second and third posttreatment years $\left(F_{4,15}=7.59, \quad P=0.001\right.$ and $F_{4,15}=3.09, P=0.048$, respectively; Fig. 3 ). In the second post-treatment year, prescribed fire had higher Ceanothus cuneatus seedling density than mastication, but only results from MF were significantly lower. Although MS tended to have higher seedling density than MF, there was no significant effect of season in mastication treatments. By the third treatment year, all treatments had similar seedling density, except FF that had significantly higher density of Ceanothus cuneatus seedlings than FS.

\section{Discussion}

\section{Treatment type}

Significant differences in chaparral recovery between treatments were observed, in both terms of resprouting and seed germination. In general, prescribed fire treatments resulted in higher shrub cover and seedling density than mastication treatments 3 years after treatments. Higher shrub cover after burning compared to mechanical removal was also observed in other studies in different shrubland ecosystems including shrublands in Florida (Fitzgerald and Tanner 1992), Quercus coccifera garrigue in France (Godron et al. 1981), and Mediterranean heathland (Calvo et al. 1998, 2002) and Cistus laurifolius shrubland in Spain (Tárrega et al. 1997). Conversely, shrub height and species richness was not significantly different between treatments in this study.

The lack of shrub height difference between treatments may suggest that woody species recovery during the first year after a disturbance is mainly invested in reoccupying the bare surrounding space, in the absence of competition for light (Marcos et al. 2004). Calvo et al. (1998) observed that the most pronounced increase in height occurred once the shrubs have occupied practically all their initial space, achieving similar height values 9 years after treatments. By the end of our study (3 years after treatments) shrub cover was approximately $70 \%$ in fire treatments and $40 \%$ in masticated areas, which may explain the absence of different height response among treatments. Recovery to initial shrub cover values occurred 4 years after burning in California 


\section{Adenostoma fasciculatum}

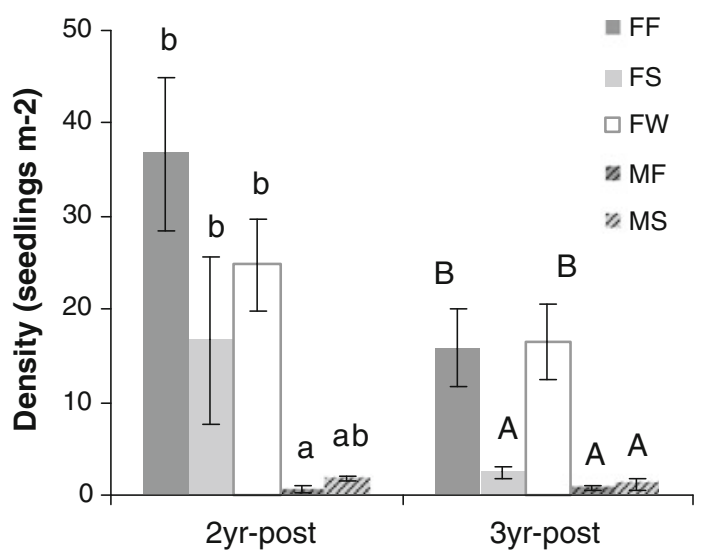

Fig. 3 Average seedling density $( \pm 1 \mathrm{SE})$ for Adenostoma fasciculatum and Ceanothus cuneatus by treatment type (FF fire fall, $F S$ fire spring, $F W$ fire winter, $M F$ mastication fall, $M S$ mastication spring) and post-treatment year. Different letters

chaparral (Dunne et al. 1991) or mechanical and fire treatments in Mediterranean heathland (Calvo et al. 1998) and garrigue (Godron et al. 1981). Gratini and Amadori (1991) reported a rapid resprouting of maquis during the first 4-5 years after a wildfire in southwestern Italy, with vegetation structure and height similar to those of initial community 8 years after fire.

Shrub germination was stimulated in the fire treatment units, resulting in higher seedling densities compared to masticated units. Similar results were reported by Baeza and Roy (2008) in a Mediterranean gorse shrubland in southeastern Spain. Although some authors reported that increased soil heating by insolation after shrub removal was enough to stimulate seed germination in chaparral (Christensen and Muller 1975), we expected lower seedling densities in the mastication treatments because the lack of fire stimuli would decrease the germination of species that require heat, char, or smoke to release dormancy (Keeley 1991).

Despite chaparral shrub-seedling density being higher in fire treatments 2 years after treatments, we observed higher mortality rates in burned plots, especially in spring fires. Our study's seedling abundance patterns are similar to trends found in other chaparral research (Beyers and Wakeman 2000; Guo 2001; Zammit and Zedler 1988) where seedling numbers are initially very high after treatment and

\section{Ceanothus cuneatus}

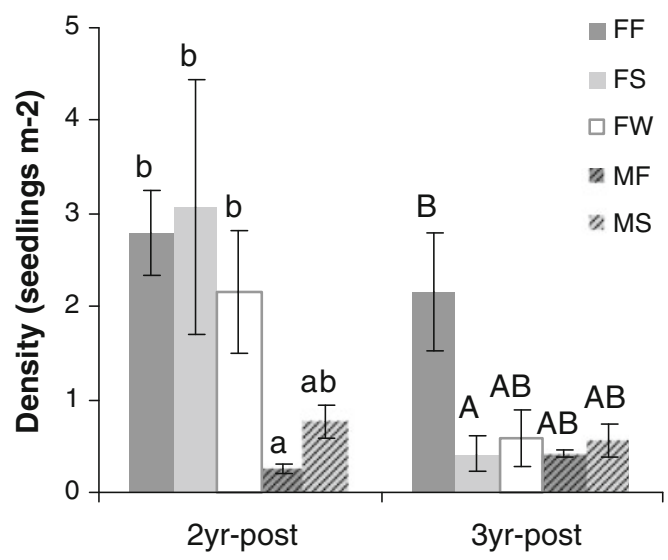

depict significantly different seedling density between treatments for the second year (lower cases) and third year (upper case) for a significance level $\alpha=0.05$

then suffer significant mortality in subsequent years. Drastic mortality rates in the early recovery years can be caused by a combination of factors, including competition, herbivory, and the insufficient root development to handle summer drought conditions.

Seed bank loss can largely be attributed to erosion (Keeley 1977) and coincidence of bare soil and heavy rain may increase erosion (Fernández et al. 2008; Gill and Groves 1981). Fernandez et al. (2008) reported that fuel treatments affected the initial runoff, infiltration, and erosion in a gorse shrubland community in northwest Spain, especially after prescribed burning compared to mastication.

Initial lower seedling density in mastication areas may explain the negligible mortality observed due to increased soil water resources caused by fewer plants (Moreno and Oechel 1991). However, Holmgren et al. (2000) reported higher seedling survival in burned plots when compared to mechanically cleared plots in Chilean shrubland. These authors observed that early seedling survival was higher under the shade of large shrubs. Initial germination and seedling survival after fuel treatments is critical in chaparral as seedling recruitment is rare until the next disturbance occurs (Keeley 1987). Despite the high seedling mortality observed in fire treatments, our results still demonstrated higher seedling densities in fall and winter burnings compared to spring burning and mastication 3 years after the treatments. 
Greater shrub recovery following fire may be explained by the large nutrient release that results from biomass combustion and ash deposition (Christensen 1973; Christensen and Muller 1975; DeBano et al. 1979; Rundel and Parsons 1980). Masticated sites, in contrast, have a slow nutrient release as the shredded biomass decays and this may contribute to the slower regrowth. Even though regeneration mechanisms of chaparral species are considered adapted to fire, the results of our and other studies in Mediterranean shrublands suggest that these communities have a high resilience to disturbance, either caused by fire or by mechanical treatments (Calvo et al. 1998; Del Barrio et al. 1999; Bond and Midgley 2001; Potts and Stephens 2009). Furthermore, nonfire disturbances are demonstrated to play an important role in the evolution of some chaparral communities (Ackerly 2004). The presence of fire-following species in masticated areas (Potts and Stephens 2009) may be attributed to polymorphic seed banks (Keeley 1991; Sweeney 1956; Zammit and Zedler 1994) and/ or sufficiently high solar heating that overcomes physical seed dormancy (Baskin and Baskin 1998; Christensen and Muller 1975). Calvo et al. (2002) observed that differences in shrub cover after different fuel treatments (including burning and cutting) during the first year of succession in a Mediterranean heathland tended to be eliminated after 12 years, and most of the species tended to recover to their initial cover values.

The number of shrub species did not differ between fire and mechanical treatments in our study. A similar result was found by Fitzgerald and Tanner (1992) in chaparral and by Calvo et al. (2005) in Mediterranean shrubland ecosystems. Regarding species composition, Adenostoma remained the dominant species after disturbance, showing higher total cover after fire than mechanical treatments, but similar relative cover between treatments. This pattern was expected considering pre-treatment $A d$ enostoma dominance and the species' ability to both resprout after top-kill and germinate from a soilstored seed bank (Odion and Davis 2000). The versatile adaptation of facultative seeders may be an advantage for recovering in a wide range of environmental conditions occurring after disturbances (Seligman and Henkin 2000).

Non-dominant species, such as Ceanothus cuneatus, had different responses than the dominant species. Ceanothus is of particularly strong interest to land managers due to its nutritional value to many browsing wildlife species (Biswell 1974), including black-tailed deer. By the third year after treatments, Ceanothus cuneatus total cover was still low because this species only regenerates by germination, showing slightly higher relative cover in fall burn treatments than in the spring and winter burn treatments. Nevertheless, the slow recovery of Ceanothus may not be detrimental to this species. Once seedlings are established and nitrogen availability decreases following the initial flush immediately post-fire, nitrogen-fixing species, such as Ceanothus, should have an increasing competitive advantage over non-symbiotic shrubs (Ellis and Kummerow 1988), especially in nitrogen-limited ecosystems like chaparral (Rundel and Parsons 1980). In Adenostoma dominated chaparral, Davis (1967) reported Ceanothus cover increased 10 years after fire in southern California.

\section{Treatment season}

Season of treatment did not significantly affect shrub resprouting in our study. Results on treatment season effects are varied in the literature. Fitzgerald and Tanner (1992) also found no effects of season on either fire or mechanical treatments in shrublands in Florida. These authors argued that soil moisture affects post-treatment recovery and explained the absence of difference in their study to relatively low moisture levels in both seasons when the treatments were applied (winter and summer). Dunne et al. (1991) also reported no negative effect of fall burns on chaparral recovery and Godron et al. (1981) did not observe any difference in vegetation cover between fall and spring burn treatments in French garrigue. Radosevich and Conard (1980) reported no effect on post-fire Adenostoma shoot growth between burning seasons in northern California chaparral. These authors argued that post-fire growth is not dependent on the water status of the shrub before the burning time, but on subsequent suitable environmental conditions.

Conversely, Moreno and Oechel (1991) reported that increasing fire intensity increased plant mortality, reduced the number of resprouts per plant, and delayed the time of resprouting in chaparral. Similar results were found by Lloret and Lopez-Soria (1993) in the Mediterranean shrub Erica multiflora when 
applying higher intensity fire to individual plants. Florence and Florence (1988) also reported increased Adenostoma mortality at high fire intensity when burns were conducted during the growing or flowering season. However, Canadell et al. (1991) did not observe differences in the biomass of resprouts of individual shrubs burned at different fire intensities in a Mediterranean shrubland. Our findings conflict with some previous research that found lower shrub sprouting after spring prescribed fire in southern California chaparral (Beyers and Wakeman 2000).

Although season of treatment did not have a strong influence on shrub reprouting, season of treatment did have a significant influence on seedling density. Fall and winter fire treatments had higher seedling densities than any other treatment. We expected high seedling densities in fall fire treatments because this treatment best approximates California chaparral wildfire regimes before fire suppression (Stephens et al. 2007). However, we were surprised to observe substantial seedling recruitment after the winter fire treatments, since moist soil conditions at the time of burning have been shown to hinder seedling success for some species (LeFer and Parker 2005). Laboratory germination research by Lefer and Parker (2005) has demonstrated that Adenostoma seeds are sensitive to heat under moist soil conditions due to the amount of water absorbed into the seed and the lack of a hard seed coat. Adenostoma seedling densities did not vary between the three burning seasons 2 years after treatments, and remained nearly identical in the fall and winter fire treatments by the third year after subsequent mortality. Mastication treatments also showed similar seedling densities for this species between fall and spring.

We expected the spring treatments to have the lowest seedling densities, since germinating plants have an insufficient time and resources to develop drought-surviving root systems prior to the hot, dry Mediterranean summer (Mooney and Parsons 1973; Bond et al. 1984; Saruwatari and Davis 1989). Our seedling mortality data confirm this hypothesis. The highest seedling mortality was observed in spring burning for both Adenostoma and Ceanothus seedlings indistinctively ( 85 and $87 \%$, respectively). Fall burning, where fire behavior and effects are expected to be more similar to wildfire in chaparral communities, resulted in more than $50 \%$ seedling mortality for Adenostoma compared to $<23 \%$ for
Ceanothus. Winter burning resulted in lower seedling mortality in Adenostoma (33\%) compared to Ceanothus (72\%).

Although, the ability of a seed to develop adequate roots prior to summer drought may be the strongest influence on seedling mortality, functional group characteristics may also be an important factor in determining seedling mortality and survival. Consistent with our findings, other studies have reported higher mortality in facultative seeder species compared to obligate seeder species after wildfire (Frazer and Davis 1988; Thomas and Davis 1989) and fall burning (Odion and Davis 2000) in southern California chaparral, suggesting that the lack of resprouting ability among obligate seeders is offset by an enhanced ability to establish seedlings after fire. Another chaparral study reported that obligate seeders seedling are better adapted to water stress, demonstrating higher survival rates in open gaps and without shading from adjacent shrub canopies (Pratt et al. 2008).

Regarding mastication, although fall and spring treatments had similar seedling densities, season seemed to affect seedling mortality in a very different manner, with fall mastication even showing seedling recruitment by the third year for both Adenostoma and Ceanothus. Our results suggest that, in the absence of fire-enhancing germination, seedling establishment after fall mastication treatments occurred for at least 3 years.

\section{Herbivory}

This study demonstrated a relative effect of herbivores on vegetation regrowth at our treatment scale. Shrub height was higher in the exclosed areas 3 years after treatment; however, cover was not significantly affected. Although treatment type had no significant effect on shrub height, the herbivory effect was higher in mastication compared to fire treatments. This could be explained by the presence of plant skeletons after burning, not present after mastication, which may interfere with large mammal movement preventing access to basal sprouts (Davis 1967). It is important to note that our relatively small twohectare treatment areas may have lead to intense browsing pressure due to their placement in an otherwise dense chaparral matrix. Larger treatment areas may experience less browsing pressure. 
Our results suggest that large herbivores do not extensively browse shrub seedlings in the early years following disturbance, since seedling abundance was similar in exclosed and unexclosed areas (at least at the spatial scales examined here). Previous herbivory studies in California chaparral also found no significant exclosure effects on vegetation recovery (Tyler 1995, 1996). However, these results are in contrast to other studies (Mills 1983, 1986) where differences in seedling density were found between exclosed and unexclosed areas. Nevertheless, it should be pointed out that, in our study, the exclosures were only effective against large mammals, i.e., black-tailed deer, and probably did not prevent herbivory from smaller mammals, such as rabbits or mice.

\section{Management implications}

In order to improve black-tailed deer habitat, prescribed fire would be most beneficial in fall, since it produces significantly higher Ceanothus cuneatus seedling density after the third post-treatment year. In general, spring fire treatment could be detrimental due to the lower seedling survival rates due to summer drought. Regarding mechanical treatments, fall and spring mastication resulted in similar seedling densities, although fall treatments for both fire and mastication reduced seedling mortality as seedlings had more time to develop adequate roots systems prior to the summer drought.

From a wildlife management standpoint, fire treatments have faster, denser shrub regrowth, which may encourage wildlife recovery within a short time after fuel treatment. However, regarding wildfire prevention, mastication treatments are more effective in terms of shrub fuel-load accumulation because they have dramatically slower shrub regrowth, and therefore, reduce potential fire intensity in case of a wildfire. However, fire hazards would probably be higher in masticated areas compared to those treated with prescribed fire in the short-term because newly masticated areas have fine dead fuels on the ground (Bradley et al. 2006) and increase non-native grass cover (Potts and Stephens 2009).

In the past, limited plant recovery data has hindered fuels management decisions and caused potentially detrimental management actions. Regional differences in plant response, reliance on post-wildfire data (due to a lack of prescribed fire data), and the almost complete absence of mastication research have contributed to the confusion. Despite this complex decision environment, it is important for managers to make the most responsible decisions based on their objectives. The goal of our research was to provide managers and scientists with data to reduce previous uncertainty. Clearly, more research will be needed to fill in the remaining gaps in knowledge and test the findings of this study in the long-term and in other geographic regions.

Acknowledgments We thank the US Joint Fire Science Program (Project \#00-2-02) and the USFS Riverside Fire Lab (David Weise) for funding this research, and our project cooperators from the Bureau of Land Management Ukiah Field Office (BLM), University of California Hopland Research and Extension Center (HREC), and California Department of Forestry and Fire Protection Mendocino and Lake County Units (CALFIRE). We extend special thanks to J. Dawson (BLM), R. Keiffer (HREC), T. Derum (CALFIRE), M. Tolbert (CALFIRE), and W. Baxter (CALFIRE). We also extend our gratitude to numerous field assistants, particularly D. Fry, who also reviewed this manuscript. Eva Marino's participation in this research was possible through a Ph.D. scholarship funded by INIA (Instituto Nacional de Investigación y Tecnología Agraria y Alimentaria), Spain.

Open Access This article is distributed under the terms of the Creative Commons Attribution Noncommercial License which permits any noncommercial use, distribution, and reproduction in any medium, provided the original author(s) and source are credited.

\section{References}

Ackerly D (2004) Functional strategies of chaparral shrubs in relation to seasonal water deficit and disturbance. Ecol Monogr 74:25-44

Baeza MJ, Roy J (2008) Germination of an obligate seeder (Ulex parviflorus) and consequences for wildfire management. For Ecol Manag 256:685-693

Baskin CC, Baskin JM (1998) Seeds: ecology, biogeography, and evolution of dormancy and germination. Academic Press, San Diego

Beyers JL, Wakeman CD (2000) Season of burn effects in Southern California chaparral. In: Keeley JE, Baer-Keeley M, Fotheringham CJ (eds) 2nd Interface between Ecology and Land Development in California. U.S. Geological Survey Open File Report 00-62, pp 45-55

Biswell HH (1974) Effects of fire on chaparral. In: Kozlowski TT, Ahlgren CE (eds) Fire and ecosystems. Academic Press, New York

Bond WJ, Midgley JJ (2001) Ecology of sprouting in woody plants: the persistence niche. Trends Ecol Evol 16:4551 
Bond WJ, van Wilgen BW (1996) Fire and Plants. Chapman and Hall, London

Bond WJ, Vlok J, Viviers M (1984) Variations in seedling recruitment of Cape Proteaceae after fire. J Ecol 72:209221

Bradley T, Gibson J, Bunn W (2006) Fire severity and intensity during spring burning in natural and masticated mixed shrub woodland. USDA Forest Service Proc. RMRS-P-41

Calvo L, Tárrega R, Luis E (1998) Space-time distribution patterns of Erica australis L. subsp. aragonensis (Willk) after experimental burning, cutting, and ploughing. Plant Ecol 137:1-12

Calvo L, Tárrega R, De Luis E (2002) The dynamics of Mediterranean shrubs species over 12 years following perturbations. Plant Ecol 160:25-42

Calvo L, Tárrega R, Luis E, Valbuena L, Marcos E (2005) Recovery after experimental cutting and burning in three shrub communities with different dominant species. Plant Ecol 180:175-185

Canadell J, Lloret F, López-Soria L (1991) Resprouting vigour of two Mediterranean shrub species after experimental fire treatments. Vegetatio 95:119-126

Christensen NL (1973) Fire and the nitrogen cycle in California chaparral. Science 188:66-68

Christensen NL, Muller CH (1975) Effects of fire on factors controlling plant growth in Adenostoma chaparral. Ecol Monogr 45:29-55

Davis J (1967) Some effects of deer browsing on chamise sprouts after fire. Am Midl Nat 77:234-238

DeBano LF (2000) The role of fire and soil heating on water repellency in wildland environments: a review. J Hydrol 231-232:195-206

DeBano LF, Rice RM, Conrad CE (1979) Soil heating in chaparral fires: effects on soil properties, plant nutrients, erosion and runoff. USDA Forest Service, PSW-145

Del Barrio J, Luis-Calabuig E, Tárrega R (1999) Vegetative response of Arctostaphylos uva-ursi to experimental cutting and burning. Plant Ecol 145:191-195

Drewa PB, Platt WJ, Moser EB (2002) Fire effects on resprouting of shrubs in headwaters of southeastern longleaf pine savannas. Ecology 83:755-767

Dunne J, Dennis A, Bartolome JW (1991) Chaparral response to a prescribed fire in the Mount Hamilton range, Santa Clara county, California. Madroño 38:21-29

Ellis BA, Kummerow $\mathbf{J}(1988) \mathrm{N}_{2}\left(\mathrm{C}_{2} \mathrm{H}_{2}-\mathrm{C}_{2} \mathrm{H}_{4}\right)$ fixation in two species of Ceanothus seedlings in second year postfire chaparral. Plant Soil 109:207-213

Fernández C, Vega JA, Fonturbel T, Jiménez E, Pérez JR (2008) Immediate effects of prescribed burning, chopping and clearing on runoff, infiltration and erosion in a shrubland area in Galicia (NW Spain). Land Degrad Dev 19:502-515

Fitzgerald SM, Tanner GW (1992) Avian community response to fire and mechanical shrub control in south Florida. J Range Manag 45:369-400

Florence SR, Florence MA (1988) Prescribed burning effects in Central California chaparral. Rangelands 10:138-140

Frazer JM, Davis SD (1988) Differential survival of chaparral seedlings during the first summer drought after wildfire. Oecologia 76:215-221
Gill AM, Groves RH (1981) Fire regimes in heathlands and their plant-ecological effects. In: Specht RL (ed) Ecosystems of the world: heathland and related shrublands. Elsevier, Amsterdam, pp 61-82

Gill AM, Stephens SL (2009) Scientific and social challenges for the management of fire-prone wildland-urban interfaces. Environ Res Lett 4:034014

Godron M, Guillerm JL, Poissonet J, Poissonet P, Thiault M, Trabaud L (1981) Dynamics and management of vegetation: effects of fire and grazing on Quercus coccifera garrigue. In: Di Castri F, Goodhall DW, Specht RL (eds) Mediterranean-type shrublands. Elsevier, Amsterdam, pp 317-347

Gratini L, Amadori M (1991) Post-fire resprouting of shrubby species in Mediterranean maquis. Vegetatio 96:137-143

Guo Q (2001) Early post-fire succession in California chaparral: changes in diversity, density, cover and biomass. Ecol Res 16:471-485

Hanes TL (1971) Succession after fire in the chaparral of southern California. Ecol Monogr 41(1):27-42

Holmgren M, Segura AM, Fuentes ER (2000) Limiting mechanisms in the regeneration of Chilean matorral. Plant Ecol 147:49-57

Keeley JE (1977) Seed production, seed populations in soil, and seedling production after fire for two congeneric pairs of sprouting and nonsprouting chaparral shrubs. Ecology 58:820-829

Keeley JE (1987) Role of fire in seed germination of woody taxa in California chaparral. Ecology 68:434-443

Keeley JE (1991) Seed germination and life history syndromes in the California chaparral. Bot Rev 57:81-116

LeFer D, Parker VT (2005) The effect of seasonality on burn on seed germination in chaparral: the role of soil moisture. Madroño 52:166-174

Lloret F, Lopez-Soria L (1993) Resprouting of Erica multiflora after experimental fire treatments. J Veg Sci 4:367-374

Manier DJ, Hobbs NT (2007) Large herbivores in sagebrush steppe ecosystems: livestock and wild ungulates influence structure and function. Oecologia 152:739-750

Marcos E, Tárrega R, Luis-Calabuig E (2004) Interactions between Mediterranean shrub species eight years after experimental fire. Plant Ecol 170:235-241

Mills JN (1983) Herbivory and seedling establishment in postfire southern California chaparral. Oecologia 60:267-270

Mills JN (1986) Herbivores and early postfire succession in Southern California chaparral. Ecology 67:1637-1649

Mooney HA, Parsons DJ (1973) Structure and function of the California chaparral: an example from San Dimas. In: Di Castri F, Mooney HA (eds) Mediterranean type ecosystems. Springer, New York, pp 83-112

Moreno JM, Oechel WC (1991) Fire intensity and herbivory effects on postfire resprouting of Adenostoma fasciculatum in southern California chaparral. Oecologia 85:429433

O'Neil SE, Parker VT (2005) Factors contributing to the soil seed bank size of two obligate seeding Ceanothus species in Northern California. Madroño 52:182-190

Odion DC, Davis FW (2000) Fire, soil heating, and the formation of vegetation patterns in chaparral. Ecol Monogr 70:149-169 
Potts JB, Stephens SL (2009) Invasive and native plant responses to shrubland fuel reduction: comparing prescribed fire, mastication, and treatment season. Biol Conserv 142:1654-1657

Pratt RB, Jacobsen AL, Mohla R, Ewers FW, Davis SD (2008) Linkage between water stress tolerance and life history type in seedlings of nine chaparral species. $\mathrm{J}$ Ecol 96:1252-1265

Radosevich SR, Conard SG (1980) Physiological control of chamise shoot growth after fire. Am J Bot 67:1442-1447

Rundel PW, Parsons DJ (1980) Nutrient changes in two chaparral shrubs along a fire-induced age gradient. Am J Bot 67:51-58

Saruwatari MW, Davis SD (1989) Tissue water relations of three chaparral shrub species after wildfire. Oecologia 80:303-308

Seligman NG, Henkin Z (2000) Regeneration of a dominant Mediterranean dwarf-shrub after fire. J Veg Sci 11:893902

Stephens SL, Martin RE, Clinton NE (2007) Prehistoric fire area and emissions from California's forests, woodlands, shrublands and grasslands. For Ecol Manag 251:205-216

Stephens SL, Weise DR, Fry DL, Keiffer RJ, Dawson J, Koo E, Potts J, Pagni P (2008) Measuring the rate of spread of chaparral prescribed fires in northern California. Fire Ecol 4:74-86

Stephens SL, Moghaddas JJ, Ediminster C, Fiedler CE, Hasse $\mathrm{S}$, Harrington M, Keeley JE, McIver JD, Metlen K,
Skinner CN, Youngblood A (2009) Fire treatment effects on vegetation structure, fuels, and potential fire severity in western U.S. forests. Ecol Appl 19:305-320

Sweeney JR (1956) Responses of vegetation to fire: a study of the herbaceous vegetation following chaparral fires. Univ Calif Publ Bot 28:143-249

Tárrega R, Luis-Calabuig E, Alonso I (1997) Space-time heterogeneity in the recovery after experimental burning and cutting in a Cistus laurifolius shrubland. Plant Ecol 129:179-187

Thomas CM, Davis SD (1989) Recovery patterns of three chaparral shrub species after wildfire. Oecologia 80:309320

Tyler CM (1995) Factors contributing to postfire seedling establishment in chaparral: direct and indirect effects of fire. J Ecol 83:1009-1020

Tyler CM (1996) Relative importance of factors contributing to postfire seedling establishment in maritime chaparral. Ecology 77:2182-2195

Wells PV (1969) The relation between mode of reproduction and extent of speciation in woody genera of the California chaparral. Evolution 23:264-267

Zammit CA, Zedler PH (1988) The influence of dominant shrubs, fire and time since fire on soil seed banks in mixed chaparral. Vegetatio 75:175-187

Zammit CA, Zedler PH (1994) Organization of the soil seed bank in mixed chaparral. Vegetatio 111:1-16 